\title{
POLAND'S ECONOMIC SECURITY IN THE CONTEXT OF GLOBALISATION PROCESSES
}

\author{
Konrad STAŃCZYK \\ University of Technology, Warsaw; konrad.stanczyk@wat.edu.pl, ORCID: 0000-0003-2788-5358
}

Purpose: The purpose of the article is to make a general diagnosis of Poland's economic security in the context of globalization processes.

Design/methodology/approach: This purpose is to be achieved by indicating the main threats and opportunities for Poland's security in the context of globalization. This diagnosis will be made using analysis methods of available scientific and substantive sources of information and using statistical tools, including descriptive statistics.

Findings: The content of the article characterizes the category of economic security and describes the globalization process to finally combine these phenomena and relate them to the current situation in Poland.

Social implications: The phenomenon of globalisation, which has expanded in the modern world, brings certain benefits as well as threats. Global economic integration can stimulate development, but also become a source of restrictions for national economies. It therefore affects the level of economic security.

Originality/value: The article shows that when it comes to threats to Poland's economic security, which depend on the globalisation process, they mainly refer to the unevenness of the importance of partners in economic relations, dependence on the supply of raw materials and energy from one partner and forcing restrictions on participation in international exchange. The results can be interesting for those seeking knowledge of the economic security of the state, including students studying fields related to security.

Keywords: economic security, organisation and management of State security, security science, economic security management.

Category of the paper: The article has a theoretical and empirical character and concerns issues related to the economic security of the state. 


\section{Introduction}

The contemporary perception of the world differs from the classical approach in the geographical sense. Increasingly, in various areas of the functioning of entities of international relations, there is an economic perception of individual areas of the world as potential markets for goods, locations for making investments and searching for rational labour markets.

Nowadays, State economies acquire new features that generate specific threats. This mainly concerns problems generated by: interdependence between national economies, progressive global competition, exclusion of economic processes from the control of States, structural dependence of national economies on international systems and international formal and legal solutions, a significant increase in the number and strength of non-State actors, i.e. transnational corporations, the activity of which ignores the laws of individual countries, the institutionalisation of economic life and the virtualisation of money and financial transactions.

In international terms, the contemporary security architecture is further complicated not only by the inter-State but, above all, the cross-border nature of threats, which, in relation to the sphere of economic activity, result from the impact of capital markets, the use of speculative capital and the activities of transnational corporations.

Nowadays, in the face of globalisation, transnational corporations, the occurrence of global financial crises and the depletion of natural resources and energy are gaining in importance. This reorientation undoubtedly strengthens the isolation of the economic security category.

Economic security is the ability of the economic system of a State (group of States) to use internal factors of development and international economic interdependence, which will guarantee its unimpeded development (Frejtag-Mika et al., 1996).

The purpose of this study has both a theoretical and a utilitarian character. In the theoretical part, the purpose of this article is to present the essence of economic security in the context of contemporary globalisation. In the practical part, the aim of the study is to present the threats and opportunities of globalisation processes and to characterise the impact of these processes on the state of Poland's economic security.

\section{The Essence of Economic Security}

Economic security means protecting the State against external threats, which must include a state of guaranteeing security at both a macro and micro level. At the macro level, this means the need to ensure the physical capabilities of the State (infrastructure), while at the micro level - the possibility of generating profits by multinational companies or the possibility of migration. Policy makers must remember that both levels of economic security are interconnected (De Souza, 2000). 
Therefore, a smaller or greater extent of State interference in the economy is unavoidable. Economic security is thus a derivative of the state of the political and economic system, because the manner in which politicians regulate the rules of business entities and the mutual relations between them and State institutions, as well as the principles of international relations, affects the level of economic security of the State (Redo, and Siemiątkowski, 2017).

The concept of "economic security" reflects not only a certain state of compliance of certain economic variables (macro and micro), but also numerous fields of threats, the reduction or overcoming of which requires the effort of the whole society. Threats can be recognised both as a result of actions taken by the States they concern and those that result from the development and functioning of the global economy (Stachowiak, 2012).

Economic security can also be considered in the national and international aspect. Ensuring the national economic security of a given country is based on: activities that guarantee the survival of society and undisturbed functioning of the economy in the event of armed conflict and the creation of economic ties with foreign countries after testing the country's susceptibility to external activities designed to weaken economic security. On the other hand, ensuring international economic security consists in shaping a better international economic order. The economic security dimensions include:

1. Financial security:

a) external (external debt and the ability to withstand financial crises),

b) internal (the ability of the public finance system to provide financing for the national economy),

2. Raw materials security (access to economically important energy resources, water, metals, minerals in the amount corresponding to the structure of the economy) (Perczyński, 1990).

Elements of financial risks for economic security are: too high level of foreign debt, occurrence of financial crises, money laundering, functioning of a tax haven. These occur together or separately.

Elements of a subset of the raw materials and energy threats to the economic security of States are lack of availability of: oil and natural gas, electricity, copper, zinc, other strategic and rare raw materials (vide: Księżopolski, 2004).

The types of external and internal threats to State security of an economic nature are presented in table (Table 1).

External threats - this is a type of threat that increases the likelihood of losing or reducing the sovereignty or economic integrity (including territorial) of the State. The source of this threat is another country (Słownik, 2002).

Internal threats - this is a type of threat that results in the likelihood of a reduction in the ability of the authorities to maintain order or public order in the State. 
Table 1.

Typology of threats to the economic security of a country

\begin{tabular}{|l|l|}
\hline \multicolumn{1}{|c|}{ External Threats Internal Threats } & \multicolumn{1}{c|}{ Internal Threats } \\
\hline Economic dependence on other countries & Low level of tax revenues \\
\hline Foreign corporations & Growing public debt \\
\hline World crises & $\begin{array}{l}\text { A high share of the unofficial economy in the entire } \\
\text { economy }\end{array}$ \\
\hline No membership in international institutions & High level of unemployment \\
\hline $\begin{array}{l}\text { Geopolitical location in the vicinity of countries } \\
\text { with low development level, with difficult access } \\
\text { to raw materials and outlets }\end{array}$ & $\begin{array}{l}\text { Significant polarisation of the society's income and high } \\
\text { level of poverty }\end{array}$ \\
\hline Non-compliance with intellectual property rights & $\begin{array}{l}\text { Low level of innovation and competitiveness of } \\
\text { enterprises }\end{array}$ \\
\hline International criminal groups & Weak social security system \\
\hline & $\begin{array}{l}\text { Lack of stable economic policy pursued by successive } \\
\text { governments }\end{array}$ \\
\hline & $\begin{array}{l}\text { Low level of enactment and enforcement of law } \\
\text { regulating economic turnover }\end{array}$ \\
\hline & High level of corruption \\
\hline
\end{tabular}

Adapted from: “Gospodarka nieoficjalna a bezpieczeństwo ekonomiczne państwa ” by D. Ćwikowski. 2016.

Economic security means, therefore, the state of the political system and, as a consequence of it, an economic system that ensures freedom of economic activity, stability of macroeconomic conditions, relatively low bureaucratic and tax burdens regulated international trade relations to ensure comparable conditions of competition, and participation in international alliances increasing the relative resistance to the negative impact of the external environment (Siemiątkowski, 2015).

\section{The Essence and Ways of Measuring Globalisation}

The phenomenon of globalisation has swept around the world since the 1980s under the consensus that the free movement of goods, services, capital, technology and labour among countries integrates individual markets and economies for greater efficiency of resource allocation, higher productivity and more investment opportunities. However, even as globalisation has brought economic prosperity for the developing world, it has come under fire for its negative side effects. Some gain from trade openness while others lose. Fierce competition may have contributed to economic and social inequalities among individuals or countries, generating income and political polarisation, and potentially undermining social and cultural cohesion. Eventually, it was seen as a risk to economic growth and stability. The economic subordination of underdeveloped countries, the marginalisation of socioeconomically vulnerable groups and the loss of sociocultural diversity are fiercely debated as related concerns (Huh, and Park, 2019). 
Globalisation is a process that erodes national boundaries, integrates national economies, cultures, technologies and governance and produces complex relations of mutual interdependence. It describes the process of creating networks of connections among actors at intra- or multi-continental distances, mediated through a variety of flows including people, information and ideas, capital and goods (vide: Dreher, 2006).

Nye and Keohane, distinguishes between three different dimensions of globalisation (Nye, and Keohane, 2000):

1. Economic globalisation characterises long distance flows of goods, capital and services, as well as information and perceptions that accompany market exchanges.

2. Social globalisation expresses the spread of ideas, information, images and people.

3. Political globalisation characterises the diffusion of government policies.

Globalisation has been considered as an irreversible trend that improves both incomes and non-income aspects, such as security, political stability, sociocultural harmonisation, democratisation and public sensitivity to human rights and gender equality. Advocates for globalisation argue that these developments have led to economic growth and human development (United Nations Development Programme, 1999). Accordingly, globalisation has been set forth as a key strategy for economic growth and human development in economies around the world, but there is growing criticism that it has contributed to widening inequality across and within countries and has created new threats to security and social stability (Human Development Report, 1999).

To examine the consequences and causes of globalisation in more detail, we need to measure globalisation. Single indicators, often reflecting openness, such as trade as a percentage of GDP, are frequently used as a proxy for globalisation. Globalisation is, however, a multifaceted concept that encompasses much more than openness to trade and capital flows. It also includes citizens of different countries communicating with each other and exchanging ideas and information or governments working together to tackle political problems of a global reach. Consequently, scholars need to account for manifold facets of globalisation. Scholars have been active in constructing encompassing indicators of globalisation since the early 2000s. For an overview of some of the most popular globalisation indices, see Table 2.

Table 2.

Globalisation Indices - Overview and main characteristics

\begin{tabular}{|l|l|l|l|}
\hline \multicolumn{1}{|c|}{ Measure } & Years & \multicolumn{1}{c|}{ Description } & \multicolumn{1}{c|}{ Characteristics } \\
\hline $\begin{array}{l}\text { KOF } \\
\begin{array}{l}\text { Globalisation } \\
\text { Index - 2018 } \\
\text { Version }\end{array}\end{array}$ & $\begin{array}{l}1970- \\
2016\end{array}$ & $\begin{array}{l}\text { Comprehensive indicator covering the } \\
\text { economic, social and political aspects of } \\
\text { globalisation, distinguishing between de } \\
\text { facto and de jure. }\end{array}$ & $\begin{array}{l}\text { Distinction between de facto and de } \\
\text { jure globalisation for each dimension } \\
\text { and sub-dimension of the index. } \\
\text { Differentiation between trade and } \\
\text { financial globalisation. Wide coverage } \\
\text { in terms of countries and years. }\end{array}$ \\
\hline $\begin{array}{l}\text { KOF } \\
\text { Globalisation } \\
\text { Index - 2007 } \\
\text { Version }\end{array}$ & $\begin{array}{l}1970- \\
2015\end{array}$ & $\begin{array}{l}\text { Comprehensive indicator covering the } \\
\text { economic, social and political aspects of } \\
\text { globalisation. }\end{array}$ & $\begin{array}{l}\text { Wide coverage in terms of countries } \\
\text { and years. Hybrid-measure. No clear } \\
\text { distinction between trade and financial } \\
\text { globalisation. }\end{array}$ \\
\hline
\end{tabular}


Cont. table 2.

\begin{tabular}{|c|c|c|c|}
\hline $\begin{array}{l}\text { Maastricht } \\
\text { Globalisation } \\
\text { Index (MGI) - } \\
2012 \text { Edition } \\
\end{array}$ & $\begin{array}{l}2000 \\
2008 \\
2012\end{array}$ & $\begin{array}{l}\text { Comprehensive indicator covering the } \\
\text { political, economic, social \& cultural, } \\
\text { technological and environmental domain } \\
\text { of globalisation. }\end{array}$ & $\begin{array}{l}\text { Includes an environmental dimension. } \\
\text { Only covers three years. }\end{array}$ \\
\hline $\begin{array}{l}\text { A.T. Kearney/ } \\
\text { Foreign Policy } \\
\text { Globalisation } \\
\text { Index (ATK/ } \\
\text { FP) }\end{array}$ & $\begin{array}{l}2002- \\
2007\end{array}$ & $\begin{array}{l}\text { First composite indicator measuring } \\
\text { globalisation. Covers political } \\
\text { engagement, technology, personal } \\
\text { contact and economic integration on a } \\
\text { global scale. }\end{array}$ & $\begin{array}{l}\text { Serves as benchmark by many } \\
\text { alternative indices. }\end{array}$ \\
\hline GlobalIndex & $\begin{array}{l}1970- \\
2002\end{array}$ & $\begin{array}{l}\text { Sociological index of globalisation } \\
\text { covering the economic, sociotechnical, } \\
\text { cultural and political dimensions of } \\
\text { globalisation. }\end{array}$ & $\begin{array}{l}\text { Extends existing indices by additional } \\
\text { dimensions and indicators, representing } \\
\text { a sociological concept of globalisation. }\end{array}$ \\
\hline $\begin{array}{l}\text { CSGR } \\
\text { Globalisation } \\
\text { Index }\end{array}$ & $\begin{array}{l}1982- \\
2004\end{array}$ & $\begin{array}{l}\text { Composite index measuring the } \\
\text { economic, political and social aspects of } \\
\text { globalisation. Weights of variables are } \\
\text { determined by analysis of principal } \\
\text { components. }\end{array}$ & $\begin{array}{l}\text { Variables measuring openness are } \\
\text { corrected by fixed country } \\
\text { characteristics (initial population size, } \\
\text { land area and if a country is } \\
\text { landlocked). }\end{array}$ \\
\hline $\begin{array}{l}\text { New } \\
\text { Globalisation } \\
\text { Index (NGI) } \\
\end{array}$ & $\begin{array}{l}1995- \\
2005\end{array}$ & $\begin{array}{l}\text { Comprehensive indicator measuring the } \\
\text { economic, political and social aspects of } \\
\text { globalisation. }\end{array}$ & $\begin{array}{l}\text { Geographical distance helps, to some } \\
\text { extent, to distinguish globalisation } \\
\text { from regionalisation. }\end{array}$ \\
\hline $\begin{array}{l}\text { DHL } \\
\text { Connectedness } \\
\text { Indicator } \\
(\mathrm{GCI})\end{array}$ & $\begin{array}{l}2005- \\
2015\end{array}$ & $\begin{array}{l}\text { Composite indicator measuring depth } \\
\text { and breadth of a country's integration } \\
\text { with the rest of the world. Covers } \\
\text { international flows of goods and } \\
\text { services, capital, information and people. }\end{array}$ & $\begin{array}{l}\text { Distinction between depth and breadth } \\
\text { of integration. }\end{array}$ \\
\hline $\begin{array}{l}\text { KOF } \\
\text { Globalisation } \\
\text { Index }-2018 \\
\text { Version }\end{array}$ & $\begin{array}{l}1970- \\
2016\end{array}$ & $\begin{array}{l}\text { Comprehensive indicator covering the } \\
\text { economic, social and political aspects of } \\
\text { globalisation, distinguishing between de } \\
\text { facto and de jure. }\end{array}$ & $\begin{array}{l}\text { Distinction between de facto and de } \\
\text { jure globalisation for each dimension } \\
\text { and sub-dimension of the index. } \\
\text { Differentiation between trade and } \\
\text { financial globalisation. Wide coverage } \\
\text { in terms of countries and years. }\end{array}$ \\
\hline
\end{tabular}

Adapted from: “The KOF Globalisation Index - revisited” by S. Gygli, F. Haelg, N. Potrafke, J. Egbert. 2019.

Composite indicators, such as the KOF Globalisation Index, are cases in point, because they allow for combining different variables, measuring different aspects of globalisation, into one index. Several composite indicators measuring globalisation have been proposed.

The KOF Globalisation Index, introduced by Axel Dreher at the Konjunkturforschungsstelle at ETH Zurich in Switzerland, was published for the first time in 2002 and covered the period from 1970 to 2016 (Dreher, 2006). It has become the most commonly used indicator of globalisation in academic literature (Potrafke, 2015).

The KOF Globalisation Index measures the economic, social and political dimensions of globalisation. It is used in order to monitor changes in the level of globalisation of different countries over a long period. The current KOF Globalisation Index is available for 195 countries and covers the period from 1970 to 2016 . The index distinguishes between de facto and de jure globalisation in the overall index, as well as in the economic, social and political dimensions. The index measures globalisation on a scale from 1 to 100 . The figures for the constituent variables are expressed as percentiles. 42 different variables are used, which are aggregated on the basis of statistically determined weights (principle component analysis). 
The subdivision of economic globalisation contains both trade and financial globalisation. De facto trade globalisation is determined based on trade in goods and services. De jure trade globalisation includes customs duties, taxes and trade restrictions. De facto financial globalisation includes foreign investment in various categories. De jure financial globalisation includes investment restrictions, openness of the capital account and international investment agreements.

The social globalisation sub-domain in turn comprises three segments, each with its own de facto and de jure segment. Interpersonal contact is measured within the de facto segment with reference to international telephone connections, tourist numbers and migration. Within the de jure segment, it is measured with reference to telephone subscriptions, international airports and visa restrictions. Flows of information are determined within the de facto segment with reference to international patent applications, international students and trade in high technology goods. The de jure segment measures access to TV and the Internet, freedom of the press and international Internet connections. Cultural proximity is measured in the de facto segment from trade in cultural goods, international trademark registrations and the number of McDonald's restaurants and IKEA stores. The de jure area focuses on civil rights (freedom of citizens), gender equality and public spending on school education.

The sub-domain of political globalisation regarding the de facto segment is measured with reference to the number of embassies and international non-governmental organisations (NGOs), along with participation in UN peacekeeping missions. The de jure segment contains variables focussing on membership of international organisations and international treaties (KOF Globalisation Index, 2019).

\section{Threats and Opportunities for Poland's Economic Security Related to Globalisation Processes}

In post-communist countries, globalisation is inextricably linked to the process of political transformation. Poland has lived through a unique experience of transformation and development over the last 25 years. The country helped to bring down the Soviet Union in 1989 and joined NATO in 1999. Soon after the initial period of radical political and economic transition began in 1989, it entered on a path of accelerated yet stable modernisation, which, since 2004, has been supported by its membership in the European Union. The country's recipe for success could be explicated as a mixture of several far-sighted structural reforms (in local self-government, fiscal discipline, the banking sector and pension system), as well as appropriate sequencing (from the "shock therapy" at the beginning of transition, through a "big bang" introduction of four major reforms once the situation had stabilised, to the current "incrementalism"). EU structural funds have undeniably been helpful, but Poland has also 
proved to be satisfactorily efficient at investing these in line with its own development strategy and priorities (Poland as a global development partner, 2015).

One of the most important events of the last period for Poland was the admission of our country into the European Union on 1 May 2004. From then on, to an increased extent, the impact of global factors on the Polish economy has been manifested in aspects such as: trade and capital flows, liberalisation leading to increased foreign competition, absorption of innovations from technologically advanced countries, intensive labour migrations, the growing weight of global factors in shaping domestic inflation, etc. The Polish economy, along with its accession to the European Union, has benefited from: an increase in GDP, an increase in trade, both on the export and import side, as well as access to large European funds. One of the effects of integration was also an increase in the well-being of its inhabitants. On the other hand, integration has partly contributed to an increase in emigration from Poland and to the strong geographical focus of Polish exports and imports in the European Union, which largely makes the development of the Polish economy dependent on the growth of the EU economy (Gorynia, 2016).

Nowadays, after 15 years of membership, Poland has the sixth largest economy in the $\mathrm{EU}$ and has long enjoyed a reputation as a business-friendly country with a largely sound macroeconomic policy.

Poland has been pursuing a policy of economic liberalisation since 1990. During the economic slowdown in 2008-2009, it was the only EU country that avoided recession, partly due to the government's liberal fiscal policy combined with a commitment to reduce spending in the medium term (EU-wide GDP then fell by $4.4 \%$ ).

Poland is the largest recipient of EU development funds, and their cyclical allocation significantly affects the rate of economic growth. The Polish economy was doing well in the 2014-2017 period, with real GDP growth generally exceeding 3\%, partly due to an increase in government social spending, which contributed to accelerating consumption growth.

On the other hand, the government continues to clash with the EU over mandatory migrant quotas. Encouraged by a strong manufacturing sector and infrastructure investment, Poland has become a significant EU economy, although it is somewhat constrained by labour shortages in such key sectors as construction and information technology. Tensions exist between the poorer and rural eastern region of the country and the more prosperous and industrialised western region.

Poland's GDP more than doubled between 1990 and 2009, whereas in the EU27, the progress was only 33\%, and Russia managed an unimpressive $8 \%$. Poland's Human Development Index increased from 0.683 in 1990 to 0.795 in 2010, which admittedly still leaves Poland behind many Western European countries, but nevertheless demonstrates substantial progress. This has been achieved within a democratic system of government that, through consecutive parliamentary and presidential elections during the last 25 years, as well as after the traumatic 2010 presidential plane crash in Smolensk (a major test for the country's 
crisis management ability), has proved its resilience, predictability and stability. The sequencing of the Polish road to democracy and prosperity, the effort the country has placed on ensuring its sustainability and the unique formula of bridging political, economic and social transformation may provide a good example for other countries (Poland as a global development partner, 2015).

In the 2000 globalisation ranking, constructed using the KOF Index, Poland ranked 28th out of the 123 examined countries (Dreher, 2006).

In turn, in 2018, our country was ranked 31 st in 209 economies. A graphical representation of the dynamics of changes in the value of the KOF Globalisation Index for Poland since the 1970s is shown in Figure 1.

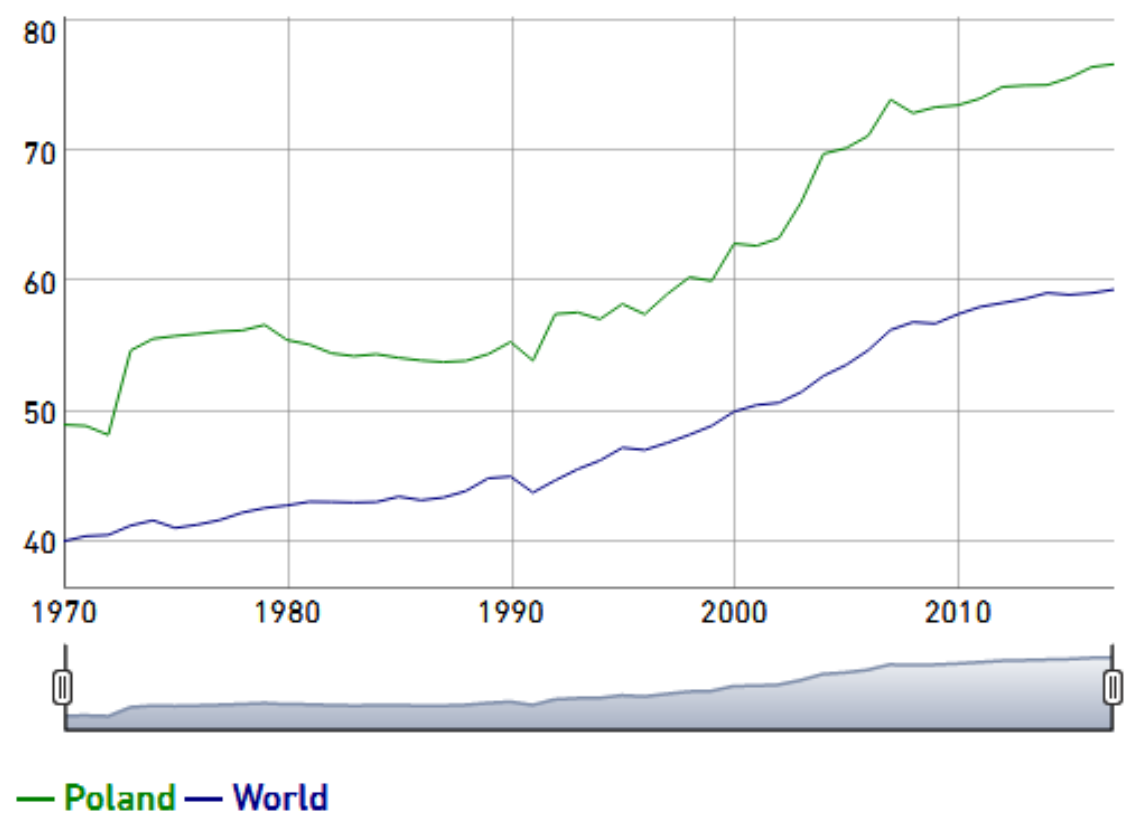

Figure 1. The KOF Globalisation Index for Poland since 1970 compared to the average global index. Adapted from: KOF Swiss Economic Institute, https://kof.ethz.ch/en/forecasts-and-indicators/ indicators/kof-globalisation-index.html (18.11.2019).

As results from the data presented in Figure 1, the highest increase in the KOF indicator was recorded from the moment of economic transformation (1991) to the moment of Poland's accession to the European Union (2004). Since 2004, the index value has remained more or less stable, with slight fluctuations.

Today, the Republic of Poland is an independent security entity, functioning as a sovereign and democratic State that implements the national interests and aspirations of citizens in the field of security, determining decent living conditions in a peaceful and stable environment, as well as achieving prosperity by its citizens while respecting the law and democratic values.

For Poland, security threats of an economic nature are associated with globalisation, expressed in the growth of international cooperation, resulting in increasing social and income inequalities. The high level of indebtedness, both public and private, which makes the country's economy exposed to an increased risk of economic crisis, is of particular importance. 
Regarding Poland, economic threats may refer mainly to:

1. Inequalities of meaning economic potential of partners in economic relations, which may be manifested in the form of dependence on foreign trade, technology, capital, etc.;

2. Dependencies on the supply (acquisition) of factors relevant to the functioning and development of the economy, such as the dependence on raw materials and energy from one partner;

3. Credit and payment dependency, expressed in the country's lack of ability to service and reduce foreign debt without a significant reduction in development and consumption;

4. Dependence on the sphere of economic regulation, expressed, for example, by the necessity of agreeing upon an economic and economic defence policy with international financial institutions;

5. Reduction of international exchange (elimination of products) in recognised as "improper" by the strongest partners, etc.

Threats to Poland's economic security also result from international economic relations, which, apart from the benefits of international division of labour and international economic trade, also create an external potential for economic threats. This can be determined at various levels, as well as in different subjective and objective systems. The most general signal of the emergence of sources of threats to Poland's economic security is the imbalance in the economic exchange with abroad (deficit).

In Poland, the next key area generating threats to economic security is energy. Currently, natural resources typical for our model of economy are exploited. Oil reserves have become exhausted throughout the world, as well as coal in Poland. Therefore, the problem of sources of energy acquisition in the future is becoming a priority from the point of view of Poland's security. The need to create a common, free gas market is also important in our region, especially as the construction of the Nord Stream 2 gas pipeline between Russia and Germany does not seem to increase the gas transmission capacity to Europe and is a Russian attempt to monopolise this market.

An area generating economic threats to Poland's security and defence is also the leaky tax system. However, this is a complex and sensitive problem, taking into account the need for the State to create a legally friendly environment for business. It seems that, in this case, solutions for the tax office utilising highly advanced tax engineering used by international holding companies may be helpful. However, it should be remembered that tax sealing cannot be carried out only in the country, because it can actually discourage cross-border companies from investing in Poland. There is a need for European integration and cooperation in this area.

Due to the need to maintain an appropriate level of economic security for the country, the priority is to understand these phenomena and prepare an appropriate response within the framework of economic policies. 


\section{Conclusion}

Economic security means protecting the State against external threats, which must include a state of guaranteeing security.

The entire Polish experience of political and economic transition followed by sustained modernisation may act as a reference point for developing countries on their way towards meeting development benchmarks (Poland as a global development partner, 2015).

In Poland, economic endeavours have been matched by a balanced foreign policy - Poland has passed from reconciliation with Germany towards establishment of amicable and functional partnership with its western neighbour; it has also managed to solidify friendly relations with a majority of countries in the region.

The most recent Russian annexation of Crimea and invasion of Ukraine constitutes a vital test for the sustainability of Poland's relations with its neighbours, as well as for Poland's capability to influence the EU foreign policy, which may affect the economic security of the country.

In recent years, one of the main events raising uncertainty as to the future of integration processes in Europe is the so-called Brexit. The results of the British referendum of 23 June 2016 to leave the structures of the European Union significantly affected the situation of a wide range of recipients - Great Britain, other members of the European Union, including Poland, the Euro area, and even the entire European region. The British decision can be seen as the beginning of a third crisis following the economic and migration crisis. The extent to which individual countries or individual industries will be affected by the consequences of Brexit depends, among others, on the shape of future UK relations with the European Union.

The Brexit problem raises concerns and causes divisions in the dialogue about the uncertain future of the entire European Union.

The never-ending migration crisis, the problem of the distribution of budget funds and other problems of a political and economic nature give rise to speculation about another exit. Although the discussion is still in the theoretical sphere, Polish enterprises must take into account a scenario in which they will face not only the consequences of Brexit, but also, for example, Polexit, which would undoubtedly significantly reduce our economic security.

In conclusion, globalisation is blamed for many socioeconomic shortcomings. Studies have reported on correlations between globalisation and economic security. Studies published more recently identify the causal effects. Evidence shows that globalisation has spurred economic growth, promoted gender equality and improved human rights. Moreover, globalisation did not erode welfare state activities, did not have any significant effect on labour market interaction and hardly influenced market deregulation. However, it did increase within-country income inequality, including in Poland. Thus, the consequences of globalisation and its impact on the level of economic security are generally much more favourable than often thought in public discourse. 


\section{References}

1. Ćwikowski, D. (2016). Gospodarka nieoficjalna a bezpieczeństwo ekonomiczne państwa. Warsaw: CeDeWu.

2. De Souza, P. (2000). Economic Strategy and National Security. Boulder: Westview, 37.

3. Dreher, A. (2006). Does globalization affect growth? Evidence from a new index of globalization. Applied Economics, 38, 10, 1091-1110.

4. Frejtag-Mika, E., Kołodziejak, Z., Putkiewicz, W. (1996). Bezpieczeństwo ekonomiczne we współczesnym świecie. Rzeszów: Wydawnictwo Politechniki Radomskiej.

5. Gygli, S, Haelg, F, Potrafke, N, Sturm, J-E. (2019). The KOF Globalisation Index revisited. The Review of International Organizations.

6. Huh, H-S, Park, S-Y. (2019). A new index of globalization: measuring impacts of integration on economic growth and income inequality. Adb Economicsworking Paper Series, 587, 1.

7. Human Development Report (1999). Globalization with a Human Face. New York: Oxford University Press.

8. Katsikides, S., Hanappi, H. (2016). Society and Economics in Europe. Cham: Springer.

9. KOF Globalisation Index for Poland since 1970, https://kof.ethz.ch/en/forecasts-andindicators/indicators/kof-globalisation-index.html, 18.11.2019.

10. KOF Globalisation Index: Globalisation Lull Continues, https://kof.ethz.ch/en/news-andevents/media/press-releases/2018/12/kof-globalisation-index-globalisation-lullcontinues.html, 18.11.2019.

11. Księżopolski, K. (2004). Ekonomiczne zagrożenia bezpieczeństwa państwa: metody i środki przeciwdziałania. Warsaw: Elipsa, 36-55.

12. Nye, J.S., and Keohane, R.O. (2000). Governance in a Globalizing World, Introduction. Cambridge, Washington: Brookings Institution Press.

13. Perczyński, M. (1990). Globalne uwarunkowania bezpieczeństwa ekonomicznego. Warsaw: Polski Instytut Spraw Międzynarodowych, 96.

14. Poland as a global development partner. Towards Poland's global engagement demos Europa - Centre for European Strategy (2015). Washington: International Bank for Reconstruction and Development The World Bank.

15. Potrafke, N. (2015). The Evidence on Globalization. The World Economy, 38, 3, 509-552.

16. Redo, M., Sięmiątkowski, P. (2017). Zewnętrze bezpieczeństwo finansowe państwa. Toruń: Wydawnictwo Naukowe Uniwersytetu Mikołaja Kopernika, 11.

17. Siemiątkowski, P. (2015). Uzależnienie finansowe jako zagrożenie bezpieczeństwa ekonomicznego państwa. Toruń: Wydawnictwo Naukowe Uniwersytetu Mikołaja Kopernika. 
18. Stownik terminów z zakresu bezpieczeństwa narodowego (2002). Warsaw: Akademia Obrony Narodowej.

19. Stachowiak, Z. (2012). Teoria i praktyka mechanizmu bezpieczeństwa ekonomicznego państwa. Ujęcie instytucjonalne. Warsaw: Akademia Obrony Narodowej, 45. 